\title{
Wybór formy zarobkowania a maksymalizacja wynagrodzenia netto. Umowa o pracę, umowy cywilnoprawne i własna działalność gospodarcza
}

\author{
Igor Postuła*, Olga Augustyniak**
}

\begin{abstract}
Przedmiotem analizy przeprowadzonej $w$ artykule jest umowa o prace, umowy cywilnoprawne (umowa o dzieło i umowa zlecenia) oraz indywidualna dziatalność gospodarcza w kontekście wysokości wynagrodzenia netto uzyskiwanego przy tych formach zarobkowania. W analizie brane sa pod uwage obciażenia z tytutu podatku dochodowego oraz sktadek na ubezpieczenia spoteczne i ubezpieczenie zdrowotne. Celem artykutu jest wykazanie, która z analizowanych form zarobkowania zapewnia maksymalne wynagrodzenie netto. Rozstrzygnięcie tej kwestii zależy przede wszystkim od wysokości rocznych przychodów przy każdej z form. Istotne jest także, jak obciażenia podatkowe $i$ sktadkowe wptywaja na ksztattowanie się wynagrodzenia netto w trakcie roku podatkowego.
\end{abstract}

Słowa kluczowe: umowy cywilnoprawne, własna działalność gospodarcza, umowa o pracę, podatki, składki na ubezpieczenia społeczne i ubezpieczenie zdrowotne.

Nadesłany: 10.09.2016 | Zaakceptowany do druku: 02.11.2016

The choice of earning form and maximization of net salary. The employment contract, civil contracts and own business

The analysis carried out in the article considers the amount of net remuneration obtained by an employment contract, civil contracts (contract of work and service contract) and individual economic activity. The analysis takes into account the burden of income tax and social and health insurance contributions. The aim of the article is to indicate which form of earning, from the analyzed in the research, provides maximum net salary. A settlement on this question depends primarily on the amount of annual revenue for each of the forms. In the article we present also how the tax burden and other contributories influence the development of net pay during the fiscal year.

\footnotetext{
Dr hab. Igor Postuła - Katedra Prawnych Problemów Administracji i Zarządzania, Wydział Zarządzania Uniwersytetu Warszawskiego.

Adres do korespondencji: Katedra Prawnych Problemów Administracji i Zarządzania, Wydział Zarządzania Uniwersytetu Warszawskiego, ul. Szturmowa 1/3, 02-678 Warszawa; e-mail: ipostula@wz.uw.edu.pl.

** Mgr Olga Augustyniak - Wydział Zarządzania Uniwersytetu Warszawskiego.

Adres do korespondencji: Katedra Prawnych Problemów Administracji i Zarządzania, Wydział Zarządzania Uniwersytetu Warszawskiego, ul. Szturmowa 1/3, 02-678 Warszawa; e-mail: olga.augustyniak@student.uw.edu.pl.
} 
Keywords: civil contracts, own business, contract of employment, taxes, social and health security contributions.

Submitted: 10.09.2016 | Accepted: 02.11.2016

JEL: K31, K34

\section{Wprowadzenie}

Zachodzące we współczesnym świecie procesy globalizacji rynku pracy, rozwoju technologii, a także rosnąca konkurencja przyczyniają się do ewolucji standardowych instytucji rynku pracy. W wyniku tego widoczne stają się tendencje zastępowania tradycyjnego stosunku pracy umowami znacznie odbiegającymi od tego wzorca. Ewolucja form zatrudnienia wprowadza nowe postrzeganie pojęcia pracy jako bardziej elastycznej, zmiennej i mobilnej. W Polsce wyrazem tej tendencji jest istotne od kilku lat znaczenie umów cywilnoprawnych oraz samozatrudnienia.

Znaczenie tych dwóch form potwierdzają dostępne raporty i dane statystyczne dotyczące różnych formy zatrudnienia i zarobkowania w Polsce i w Unii Europejskiej. Według danych Państwowej Inspekcji Pracy, w 2015 roku w podmiotach objętych jej kontrolą 13,1\% ogółu osób pracujących stanowiły osoby świadczące pracę na podstawie umów cywilnoprawnych. Spośród 13043 przeanalizowanych umów cywilnoprawnych 3482 nosiło cechy umów o pracę $(26,7 \%)$. Oznacza to, że w tych przypadkach powinny być zawierane $\mathrm{z}$ pracownikami umowy o pracę, a nie umowy cywilnoprawne (Sprawozdanie Głównego Inspektora Pracy z działalności Państwowej Inspekcji Pracy, 2016, s. 90). Według najnowszych dostępnych danych Głównego Urzędu Statystycznego, w IV kwartale 2014 roku spośród 16018000 pracujących, 2927000 osób pracowało jako samozatrudnieni (Rocznik Statystyczny Pracy, 2015, s. 135). W porównaniu $\mathrm{z}$ innymi krajami Unii Europejskiej w 2014 roku Polska znajdowała się w czołówce państw o najwyższym odsetku osób samozatrudnionych $(17,7 \%$ ogółu zatrudnionych), po Grecji i Włoszech (odpowiednio $30,4 \%$ oraz $21,9 \%$ ), przy średniej unijnej 13,5\% (Hatfield, 2015; za: Eurostat Labour Market Database, 2015). Należy mieć na uwadze, że do osób samozatrudnionych zalicza się zarówno osoby, które prowadzą działalność gospodarczą, jak i osoby, które de facto świadczą pracę na rzecz konkretnego podmiotu, mając jedynie status osoby samozatrudnionej.

Wprowadzenie elastycznych form zatrudnienia w Polsce z jednej strony „uwalnia" pracowników od ich miejsca pracy, a dla pracodawców oznacza mniejsze koszty pracy i korzystnie wpływa na konkurencyjność firm. Z drugiej strony, elastyczne formy zatrudnienia nie zapewniają stabilizacji zawodowej i poczucia pewności zatrudnienia, pozbawiają osoby zatrudnione korzystania z pełni praw pracowniczych i nierzadko wiążą się $\mathrm{z}$ obniżeniem standardów bezpieczeństwa socjalnego i stabilizacji zatrudnienia. Pomimo wielu kontrowersji występujących w dyskusjach na temat elastycznych form zatrudnienia, nie można jednoznacznie stwierdzić, że są one zjawiskiem zupełnie niekorzystnym dla osób zatrudnionych. Potencjał zatrudnienia na podstawie innej niż stosunek pracy może tkwić bezpośrednio w korzyściach finansowych dla osoby świadczącej pracę w postaci wyższego wynagrodzenia netto. Nie ulega jednak wątpliwości, że z punktu widzenia pracownika stosunek pracy jest formą najbardziej stabilną. Nie ponosi on bowiem ryzyka dotyczaceego na przykład pozyskiwania zleceń czy też utraty składników majątkowych ${ }^{1}$. Umowa o pracę umożliwia także korzystanie z płatnego urlopu oraz urlopu wychowawczego. Prowadząc działalność gospodarczą, przedsiębiorca nie korzysta z tych przywilejów. Co więcej, jest obarczony wyłączną i kompletną odpowiedzialnością za swoje decyzje.

Mając powyższe na uwadze, trzeba zdawać sobie jednak sprawę $\mathrm{z}$ faktu, że jeżeli za podstawowe kryterium różnicujące atrakcyjność rodzajów zatrudnienia przyjmiemy dochód netto, okaże się, że kwestia wyboru najlepszej umowy nie zawsze jest prosta i jednoznaczna. Celem artykułu jest wskazanie tych form zarobkowania, które są najatrakcyjniejsze z punktu widzenia maksymalizacji wynagrodzenia netto.

Wyniki przeprowadzonych badań mają przede wszystkim walor praktyczny, 
zarówno z punktu widzenia systemowego, jak i z punktu widzenia przedsiębiorców, czy osób wchodzących na rynek pracy. Znaczenie systemowe wiąże się $\mathrm{z}$ planowanymi reformami podatku dochodowego oraz składek na ubezpieczenia społeczne i ubezpieczenie zdrowotne. Według zapowiedzi obecnego rządu, na razie nieznajdujących odzwierciedlenia w projekcie ustawy ani innych oficjalnych dokumentach, te daniny mają być zastąpione jednolitym podatkiem dochodowym o charakterze progresywnym w zależności od wysokości rocznych dochodów podatnika (Kołodziej, 2016). Przy konstruowaniu takiego podatku konieczne jest odniesienie do wynagrodzenia netto z poszczególnych form zarobkowania przy różnej wysokości zarobków. Z punktu widzenia pojedynczego przedsiębiorcy czy uczestnika rynku pracy wyniki badań sa istotne, ponieważ pozwalają skalkulować wysokość wynagrodzenia netto z różnych form zarobkowania przy różnych uwarunkowaniach i wysokościach miesieccznych zarobków. Artykuł, choć bezpośrednio nie odnosi się do teorii z zakresu zarządzania nawiązuje do nurtu przedsiębiorczości w naukach o zarządzaniu. Przedsiębiorczość może być bowiem rozumiana jako identyfikacja, ocena i wykorzystanie szansy czy okazji (Timmons, 1999; Shane i Venkataraman, 2000). Decyzja co do wyboru formy zarobkowania jest decyzja wymagającą zachowań przedsiębiorczych i jako taka powinna być podejmowana w odniesieniu do rzetelnych i wiarygodnych danych dotyczących wysokości obciążeń daninami publicznymi z tego tytułu.

\section{Metodologia}

W artykule analizie poddano warianty zatrudnienia cywilnoprawnego (oddzielnie dla umowy zlecenia i umowy o dzieło), stosunku pracy oraz samozatrudnienia. W badaniu skoncentrowano się na składnikach wynagrodzenia właściwych dla poszczególnych rodzajów zatrudnienia. Przy stosunku pracy oraz umowach cywilnoprawnych analize przeprowadzono oddzielnie przy założeniu 20\% kosztów uzyskania przychodów (dalej: KUP) i przy $50 \%$ stawce tych kosztów stosowanej przy przeniesieniu praw autorskich w ramach umowy o pracę oraz umów cywilnoprawnych. Pomimo że powszechnie przyjęło się, iż 50-procentowe koszty uzyskania przycho- dów można stosować tylko w przypadku umów o dzieło, stosunek prawny, w ramach którego twórca uzyskuje przychód z praw autorskich, nie ma znaczenia. Może to być zatrudnienie zarówno na podstawie umowy o pracę, jak i umowy dzieło lub umowy zlecenia. Konieczne jest natomiast, aby twórca dokonał rozporządzenia prawami autorskimi do swojego utworu poprzez ich przeniesienie na drugą stronę umowy lub udzielenie tej stronie licencji (Wojewódzki Sąd Administracyjny w Warszawie, 2010).

Zmienność struktury całkowitego rocznego kosztu pracy w zależności od rodzaju umowy i wysokości zarobków wpływa dodatnio lub ujemnie na wielkość dochodu „na rękę” przy stosowaniu różnych form zatrudnienia. Dlatego też obliczenia i interpretacja wyników prowadzone są na podstawie sześciu różnych wysokości miesiecznego wynagrodzenia brutto: 3000 zł, 6000 zł, 9000 zł, 12000 zł, 15000 zł i 20000 zł. Tak szeroko ujęta perspektywa zarobkowania umożliwia wskazanie najbardziej atrakcyjnych rodzajów zatrudnienia dla różnych wielkości dochodu. Roczna perspektywa czasowa ma na celu uwzględnienie efektu zastosowania mniejszych stawek procentowych w pierwszych miesiącach roku i większych stawek w kolejnych miesiącach $\mathrm{z}$ tytułu przekroczenia ustawowego progu dochodowego. W badaniu wzięto także pod uwagę roczne ograniczenie podstawy wymiaru składek na ubezpieczenia emerytalne i rentowe, które w 2016 roku wynosi 121650 zł (Obwieszczenie Ministra Rodziny, Pracy i Polityki Społecznej w roku 2016 oraz przyjętej do jej ustalenia kwoty prognozowanego przeciętnego wynagrodzenia, 2015). Przyjęte roczne ramy czasowe pozwalają na uzyskanie spójnych wyników dla różnorodnych wielkości wynagrodzeń, a tym samym gwarantują ich porównywalność.

Ponadto, w celu uzyskania porównywalnych wyników, w analizie przyjęto pewne wspólne założenia dotyczące profilu osoby świadczącej pracę. Założono, że osobą tą nie jest student ani emeryt czy też rencista ze względu na duże znaczenie tego statusu dla obowiązku ZUS. Badanie w każdym $\mathrm{z}$ analizowanych przypadków przeprowadzone jest poza tym dla pełnego wymiaru czasu pracy, tj. 160 godzin w miesiącu. W sytuacji wymagającej określenia kosztów uzyskania przychodu, w każdym przypadku 
wskazywano $75 \%$ jako część czasu pracy poświęconej przygotowywaniu utworów podlegających prawu autorskiemu. Uzyskane w analizie wyniki zostały obliczone na rok podatkowy 2016 za pomocą kalkulatorów wynagrodzeń dostępnych online i uwzględniających kwestie związane z progami podatkowymi oraz kwotą wolną od podatku.

\section{Zmiana wynagrodzenia netto na przestrzeni roku w zależności formy zarobkowania}

Przedstawione poniżej zestawienie czterech rysunków (rysunek 1) przedstawia ogólne kierunki zmian wynagrodzenia netto na przestrzeni roku w zależności od czterech wybranych form zarobkowania oraz wielkości wynagrodzenia brutto. Zauważenie pewnych tendencji na wykresach pozwala zrozumieć schemat, według którego w praktyce funkcjonują składniki wynagrodzenia oraz pozwala na wyciągnię- cie wniosków co do najmniej i najbardziej korzystnych rodzajów umów.

W dalszej części analizy przedstawiona zostanie opłacalność poszczególnych rodzajów umów na tle wynagrodzeń netto w perspektywie rocznej. Na podstawie składników wynagrodzenia omówione zostaną także przyczyny opisanych powyżej tendencji oraz różnic w korzyściach finansowych w zależności od zawartej umowy.

\section{Umowa o pracę przy standardowych i autorskich kosztach uzyskania przychodu}

Różnica między zwykłym etatem a etatem z możliwością stosowania 50\% KUP sprowadza się do odmiennego wyznaczania kosztów pomniejszających podstawę opodatkowania, a co za tym idzie innej kwoty wynagrodzenia netto. Nie ulega zatem wątpliwości, że wyższe koszty uzyskania przychodu czynią etat z 50\% KUP zdecydowanie bardziej atrakcyjną propo-

Rysunek 1. Miesięczne wynagrodzenie netto z tytułu umowy o pracę, umowy zlecenia $20 \%$ KUP, umowy o dzieło 20\% KUP i umowy o dzieło 50\% KUP przy wynagrodzeniu brutto w wysokości: 6000 zt, 9000 zt, 12000 zt i 15000 zt
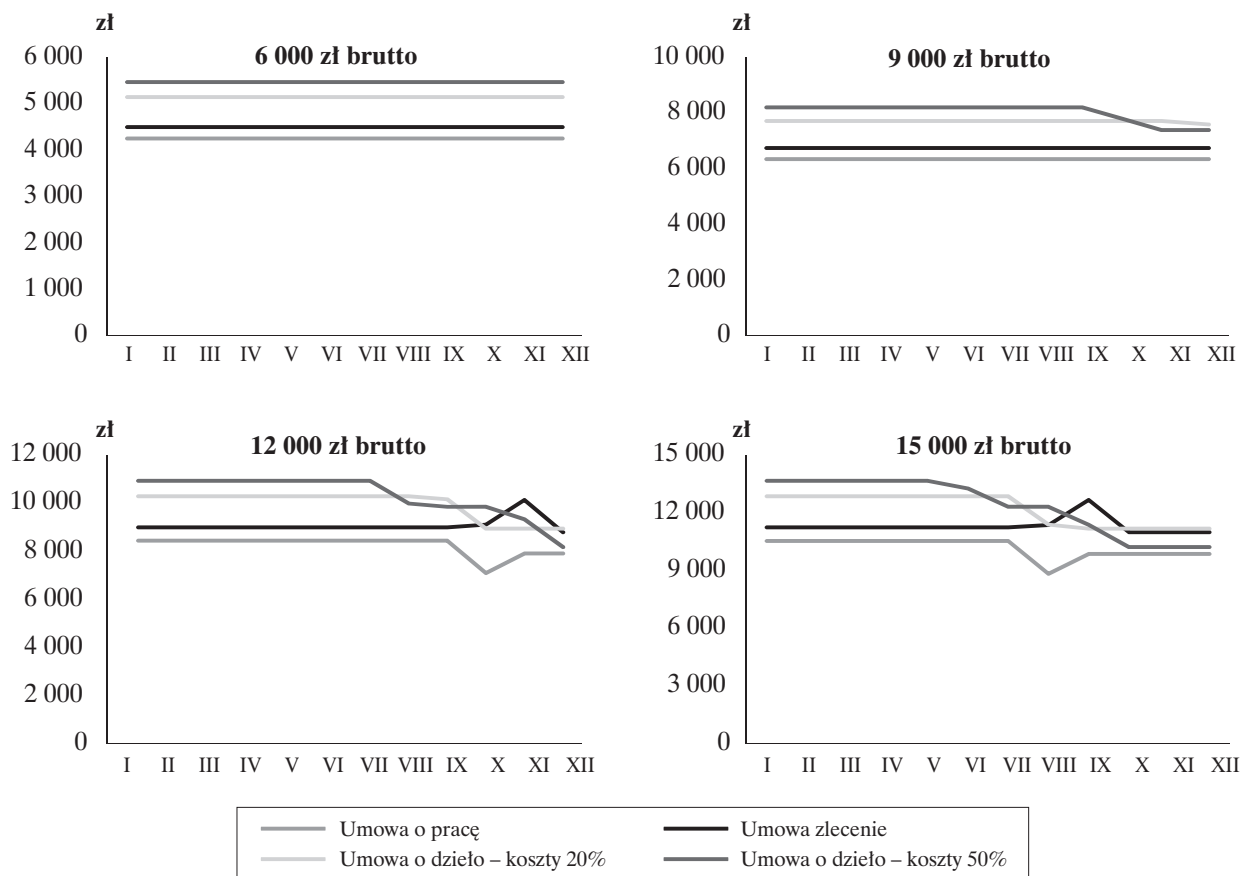

Źródło: opracowanie własne na podstawie: Kalkulator wynagrodzeń. Pozyskano z: http://samozatrudnienie.kalkulator-plac.eu/porownywarka-wysokosci-wynagrodzen (10.10.2016). 
Rysunek 2. Umowa o pracę i standardowe koszty uzyskania przychodu - miesięczne wynagrodzenie netto w perspektywie rocznej dla sześciu poziomów wynagrodzenia brutto

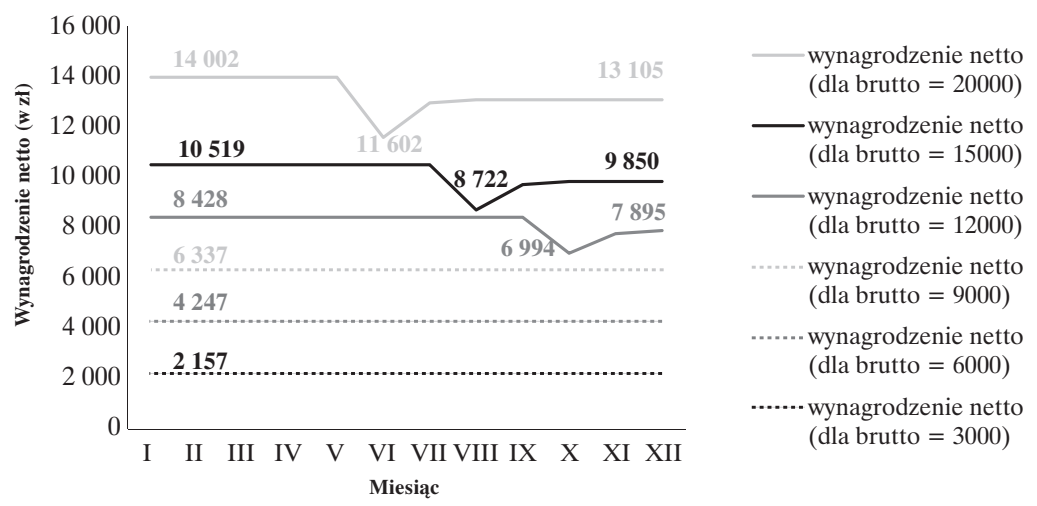

Źródło: opracowanie własne na podstawie: Kalkulator wynagrodzeń. Pozyskano z: http://samozatrudnienie.kalkulator-plac.eu/porownywarka-wysokosci-wynagrodzen (10.10.2016).

zycją. Stosowanie 50\% KUP to możliwość dostępna dla szerokiego grona pracowników, którzy w swojej pracy przygotowują różnego typu opracowania, analizy czy też procedury.

Ze względu na wejście w drugi próg podatkowy zaliczka na podatek dochodowy przy wynagrodzeniu równym $12000 \mathrm{zł}$ radykalnie wzrasta w październiku (z 995 zł do 2429 oraz ok. 2780 zł w kolejnych miesiącach). Wynagrodzenie brutto w wysokości 15000 zł powoduje wzrost zaliczki w sierpniu (z $1260 \mathrm{zl}$ do $3057 \mathrm{zl}$ oraz prawie $3500 \mathrm{zl}$ w kolejnych miesiącach), z kolei wynagrodzenie brutto równe 20000 zł oznacza zmianę zaliczki już od czerwca (zmiana z 1703 zł do 4103 zł w czerwcu oraz ponad 4600 zł w kolejnych miesiącach). Dokładnie o jeden miesiąc później wynagrodzenie brutto osiagga limit składek ZUS w postaci 30-krotności prognozowanego przeciętnego wynagrodzenia miesięcznego na dany rok (w 2016 r. jest to $121650 \mathrm{zl}$ ). Od tego miesiąca do końca roku pracownik nie odprowadza składek emerytalnych i rentowych. Część składek ZUS pracodawcy pozostaje natomiast opłacana do końca roku, jednak ulega znacznemu zmniejszeniu. Takie zbiegnięcie się w czasie wzrostu zaliczki na podatek dochodowy i redukcji składek ZUS skutkuje największym spadkiem wynagrodzenia netto $\mathrm{w}$ miesiącu zmiany wartości zaliczki, po czym wskutek „opóźnionej" o jeden miesiąc redukcji składek powoduje widoczne zwiększenie wynagrodzenia netto. Zwiększenie to nie zapewnia jednak powrotu do poziomu pierwotnego, ponieważ obniżenie niewielkich wartości składek ZUS nie jest w stanie zredukować wpływu znacznego wzrostu zaliczki na podatek.

Całkowite roczne wynagrodzenie netto $\mathrm{z}$ tytułu stosowania $\mathrm{w}$ umowie o pracę autorskich kosztów uzyskania przychodu jest przeciętnie wyższe o $10 \%$ w stosunku do stosowania standardowych kosztów uzyskania przychodu. Przy miesięcznym wynagrodzeniu brutto od $3000 \mathrm{zl}$ do $9000 \mathrm{zł}$ różnica ta wynosi $8 \%$, największa jest dla kwoty 12000 brutto, dla pozostałych dwóch analizowanych wartości wynosi odpowiednio $11 \%$ i $10 \%$. Na rysunku 3 przedstawiono tendencje zmian wynagrodzeń w poszczególnych miesiącach roku z tytułu stosowania $50 \%$ KUP.

Podobnie jak w przypadku standardowych kosztów stosowanie 50\% KUP nie powoduje zmiany wynagrodzenia netto przy kwotach brutto 3000 zł-9000 zł. W pozostałych przypadkach pierwsze modyfikacje są zauważalne w postaci wzrostów, a następnie spadków poniżej wartości początkowej. Dzieje się tak w wyniku początkowo względnie niewielkich wzrostów zaliczek na podatek dochodowy przy jednoczesnej znacznej redukcji składek ZUS. W kolejnych miesiącach zaliczka zwiększa się już w wyraźnym stopniu, podczas gdy składki ZUS ulegają dalszej tendencji spadkowej.

Radykalny spadek wynagrodzenia netto przy kwocie brutto 15000 zł jest zdeterminowany bardzo wysoką zaliczką na poda- 
Rysunek 3. Umowa o pracę i autorskie koszty uzyskania przychodu 50\% - miesięczne wynagrodzenie netto w perspektywie rocznej dla sześciu poziomów wynagrodzenia brutto
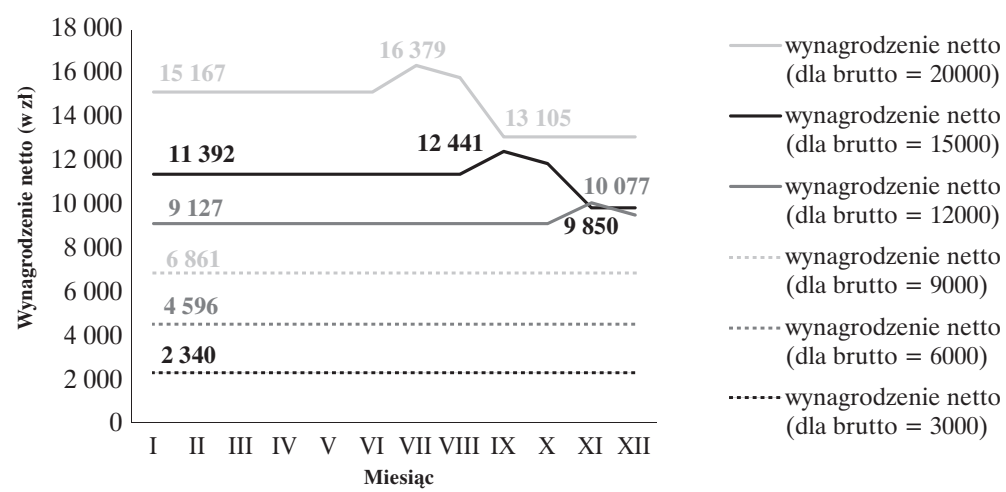

Źródło: opracowanie własne na podstawie: Kalkulator wynagrodzeń. Pozyskano z: http://samozatrudnienie.kalkulator-plac.eu/porownywarka-wysokosci-wynagrodzen (10.10.2016).

tek w listopadzie i grudniu - łącznie jest to prawie 7000 zł, podczas gdy od stycznia do sierpnia zaliczka wynosiła niecałe $400 \mathrm{zł}$. Zmniejszenie dochodu „na rękę” jest przede wszystkim konsekwencją tego, że po wyczerpaniu ustawowego limitu w wysokości 42764 zł płatnikowi nie przysługują już $50 \%$ KUP.

\section{Umowy cywilnoprawne}

\section{z zastosowaniem standardowych i autorskich kosztów uzyskania przychodu}

Zarówno przy umowie zlecenie, jak i umowie o dzieło mogą być zastosowane $20 \%$ i $50 \%$ KUP. Te drugie - jeżeli wyko- nujący dzieło lub zleceniobiorca przekazuje drugiej stronie umowy prawa autorskie. Roczne wynagrodzenie netto, wynikające z zarobkowania na podstawie umowy zlecenia (kolejno z 20\% i 50 KUP) i z umowy o dzieło (kolejno z 20\% i 50\% KUP), przy założeniu, że nie istnieją zbiegi tytułów ubezpieczeń (czyli, że dana osoba nie zarabia jednocześnie z kliku tytułów np. umowy o pracę i umowy cywilnoprawnej), przedstawiono w tabeli 1.

W każdym $\mathrm{z}$ badanych przedziałów rocznego wynagrodzenia brutto umowa o dzieło z 50\% KUP i 20\% KUP zapewniaja najwyższe wynagrodzenie netto, co wynika oczywiście z braku obowiązku opłacania składek ZUS obu stron tych umów.

Tabela 1. Roczne wynagrodzenie netto z tytułu umów cywilnoprawnych z zastosowaniem $20 \%$ i $50 \%$ KUP

\begin{tabular}{|c|c|c|c|c|}
\cline { 2 - 5 } \multicolumn{1}{c|}{} & \multicolumn{4}{|c|}{ Roczne wynagrodzenie netto (zl) } \\
\hline $\begin{array}{c}\text { Roczne wynagrodzenie } \\
\text { brutto (zl) }\end{array}$ & $\begin{array}{c}\text { Umowa zlecenia } \\
\mathbf{z} \text { 20\% KUP }\end{array}$ & $\begin{array}{c}\text { Umowa zlecenia } \\
\mathbf{z} 50 \% \text { KUP }\end{array}$ & $\begin{array}{c}\text { Umowa o dzieło } \\
\mathbf{z} 20 \% \text { KUP }\end{array}$ & $\begin{array}{c}\text { Umowa o dzieło } \\
\text { z 50\% KUP }\end{array}$ \\
\hline 36000 & 26947 & 28243 & 30816 & 32268 \\
\hline 72000 & 53894 & 56474 & 61632 & 64548 \\
\hline 108000 & 80842 & 84718 & 92448 & 96816 \\
\hline 144000 & 109911 & 114088 & 123264 & 127074 \\
\hline 180000 & 140276 & 143483 & 154080 & 156914 \\
\hline 240000 & 190887 & 192476 & 205440 & 206658 \\
\hline
\end{tabular}

Źródło: opracowanie własne na podstawie: Kalkulator wynagrodzeń netto i brutto. Pozyskano z: http:// www.pit.pl/kalkulator-wynagrodzen-netto-i-brutto/ (09.05.2016). 
Jak widać $\mathrm{z}$ analizy danych zawartych w tabeli 1 , do wysokości 108000 zł brutto rocznie, umowa zlecenia z 50\% KUP jest o prawie $5 \%$ bardziej korzystna od umowy zlecenia z 20\% KUP. Podobnie, stosowanie $50 \%$ kosztów w umowie o dzieło jest o $5 \%$ bardziej opłacalne niż stosowanie kosztów standardowych. Wyższy z badanych przedziałów rocznego wynagrodzenia brutto wiąże się $\mathrm{z}$ przekroczeniem limitu 42764 zl dla 50\% KUP oraz zmianami w wysokości składek zdrowotnej i ZUS. Należy zwrócić uwagę, że dysproporcje w zarobkach pomiędzy czterema opisanymi rodzajami umów ulegają wyraźnemu zmniejszeniu w miarę wzrostu wysokości rocznego wynagrodzenia brutto. Stosowanie podwyższonych kosztów uzyskania przychodów w umowie zlecenia i umowie o dzieło staje się coraz mniej opłacalne (ok. 3\% i poniżej 1\% różnicy odpowiednio przy wynagrodzeniu brutto $144000 \mathrm{zl}$ i 240000 zł). Podobnie, mniejsze stają się dysproporcje w zarobkach z tytułu standardowej umowy zlecenia i umowy o dzieło, gdyż zwiększona atrakcyjność finansowa umowy o dzieło ostatecznie spada dwukrotnie w stosunku do umowy zlecenia i wynosi już tylko $7 \%$ przy rocznym wynagrodzeniu brutto w wysokości 240000 z1.

Istotnym spostrzeżeniem jest zatem fakt, że aspekt korzyści finansowej przy wyborze najbardziej dogodnej umowy cywilnoprawnej odgrywa zdecydowanie większa role przy niższych zarobkach, tj. od 3000 zł do 9000 zł brutto miesięcz- nie. Jeśli natomiast wynagrodzenie kwalifikuje się już do drugiego progu podatkowego, korzyść finansowa zaczyna tracić na znaczeniu.

\section{Umowa zlecenia i umowa o dzieło z zastosowaniem $20 \%$ KUP}

W perspektywie kolejnych dwunastu miesięcy wynagrodzenie netto osoby świadczącej pracę na podstawie umowy cywilnoprawnej wyraźnie odbiega od miesięcznych tendencji charakterystycznych dla stosunku pracy, szczególnie przy wyższych wartościach wynagrodzeń brutto. Istotną przyczyna tych zmian jest sposób ustalania zaliczki na podatek dochodowy w umowie cywilnoprawnej. Od przychodów z tytułu działalności wykonywanej osobiście, a więc także umowy zlecenia i umowy o dzieło, zaliczka ta wynosi $18 \%$, niezależnie od wysokości osiaganych przychodów. Jedynie w wyjątkowych sytuacjach pobierana jest zaliczka w wysokości $32 \%$ na wniosek podatnika.

Tendencja miesięcznego wynagrodzenia netto przy zastosowaniu standardowej umowy zlecenia jest wyraźnie rosnąca (rysunek 4) w przeciwieństwie do tendencji charakterystycznej dla umowy o pracę. $\mathrm{W}$ pierwszych miesiacach roku wynagrodzenie jest oczywiście wyższe niż w przypadku etatu ze względu na brak składki chorobowej. W efekcie radykalnego spadku wysokości składek ZUS z tytułu umowy zlecenia (ma to miejsce w tych samych miesią-

Rysunek 4. Umowa zlecenia z 20\% KUP - miesięczne wynagrodzenie netto w perspektywie rocznej dla sześciu poziomów wynagrodzenia brutto

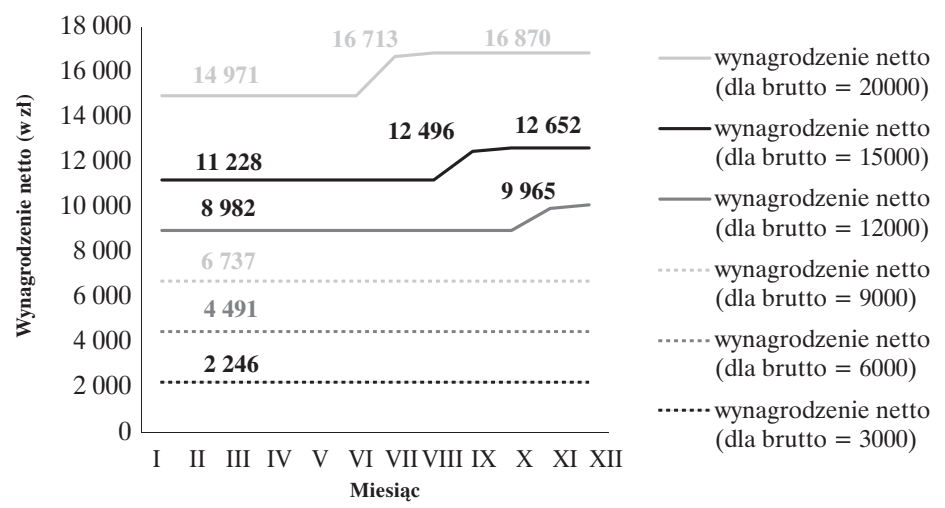

Źródło: opracowanie własne na podstawie: Kalkulator wynagrodzeń. Pozyskano z: http://samozatrudnienie.kalkulator-plac.eu/porownywarka-wysokosci-wynagrodzen (10.10.2016). 
Rysunek 5. Struktura całkowitego rocznego kosztu zleceniodawcy z tytułu umowy zlecenia z 20\% KUP

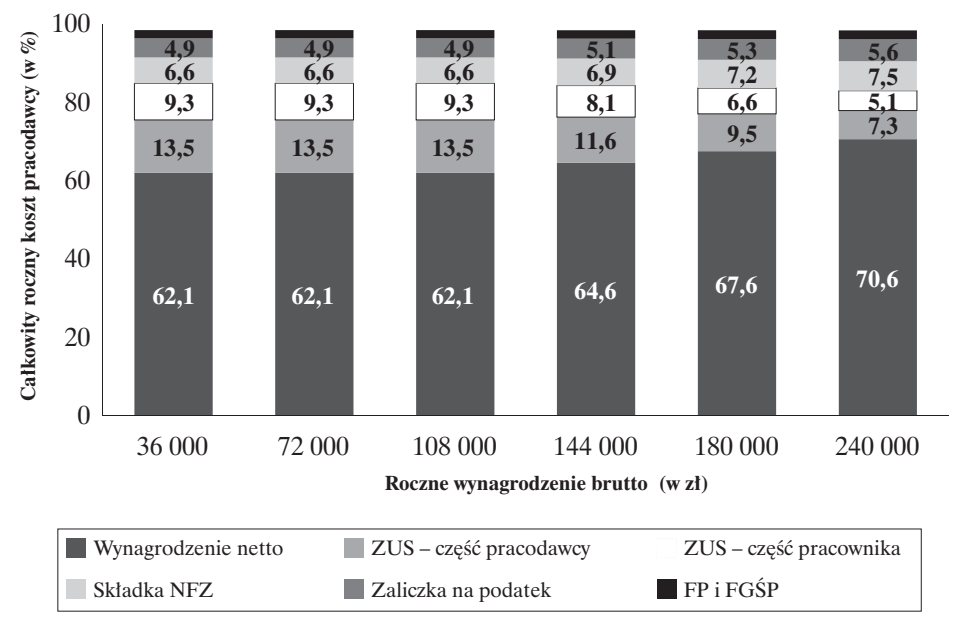

Źródło: opracowanie własne na podstawie: Kalkulator wynagrodzeń. Pozyskano z: http://samozatrudnienie.kalkulator-plac.eu/porownywarka-wysokosci-wynagrodzen (10.10.2016).

cach roku co w przypadku etatu dla danych wielkości wynagrodzeń brutto) zwiększeniu ulega zaliczka na podatek dochodowy. Jednak w tym momencie zaliczka na podatek ulega nieznacznemu zwiększeniu miesięcznemu w porównaniu do zmian w składkach ZUS pracownika i pracodawcy. Składki te zmniejszają się wówczas siedmiokrotnie, dziewięciokrotnie i dwunastokrotnie odpowiednio dla wynagrodzeń brutto w wysokości 12000 zł, 15000 zł i 20000 zł, a w pozostałych miesiącach zostają kompletnie wyeliminowane. Jednocześnie zaliczka na podatek zwiększa się o ok. $12 \%$, i obowiązuje w stałej wielkości w każdym kolejnym miesiącu do końca roku. W przekroju miesięcznym opisane powyżej zmiany prowadzą zatem do widocznych wahań zarobków netto.

Analiza umowy o dzieło z zastosowaniem standardowych kosztów uzyskania przychodu $\mathrm{w}$ wysokości $20 \% \mathrm{w}$ przekroju miesięcznym jest o wiele mniej skomplikowana. Jest to jedyny przypadek, w którym wynagrodzenie miesięczne netto wykazuje się stabilnością w każdym z badanych przedziałów zarobków brutto. Wynika to z braku podstaw do pomniejszenia podstawy opodatkowania o składki ZUS, które w tym rodzaju umowy po prostu nie funkcjonują. Dokonuje się zatem pomniejszenia przychodu jedynie o stałą wartość kosztów uzyskania przychodu. W wyniku tego zaliczka na podatek dochodowy osiąga wartość identyczną w każdym miesiącu roku. Niezmienna pozostaje zatem także struktura całkowitego rocznego kosztu zamawiającego dzieło. Niezależnie od wielkości osiaganych przychodów z tytułu umowy o dzieło stosowanie $20 \%$ KUP gwarantuje za każdym razem wynagrodzenie netto równe $85,6 \%$ całkowitego kosztu zamawiającego dzieło, który w tym przypadku stanowi jednocześnie wynagrodzenie brutto. Struktura całkowitego rocznego kosztu zleceniodawcy z tytułu umowy zlecenia z 20\% KUP wyraźnie wskazuje na rosnacy udział wynagrodzenia netto wraz ze zwiększaniem się wartości rocznych przychodów (rysunek 5). Jest to zdecydowanie rezultatem intensywnie malejących składek ZUS przy mniej radykalnie zwiększających się zaliczce na podatek i składce zdrowotnej.

\section{Umowa zlecenia i umowa o dzieło z zastosowaniem $\mathbf{5 0 \%}$ KUP}

Analogicznie do poprzedniego przykładu podstawę opodatkowania $\mathrm{z}$ tytułu umowy cywilnoprawnej z 50\% KUP otrzymuje się po pomniejszeniu przychodu o składki ZUS, a także koszty uzyskania przychodu, jednak nie większe niż 42764 zł. Po wyczerpaniu tego limitu nie istnieje już możliwość zastosowania $50 \%$ KUP. Z tego względu w przypadku trzech 
Rysunek 6. Umowa zlecenia z 50\% KUP - miesięczne wynagrodzenie netto w perspektywie rocznej dla sześciu poziomów wynagrodzenia brutto

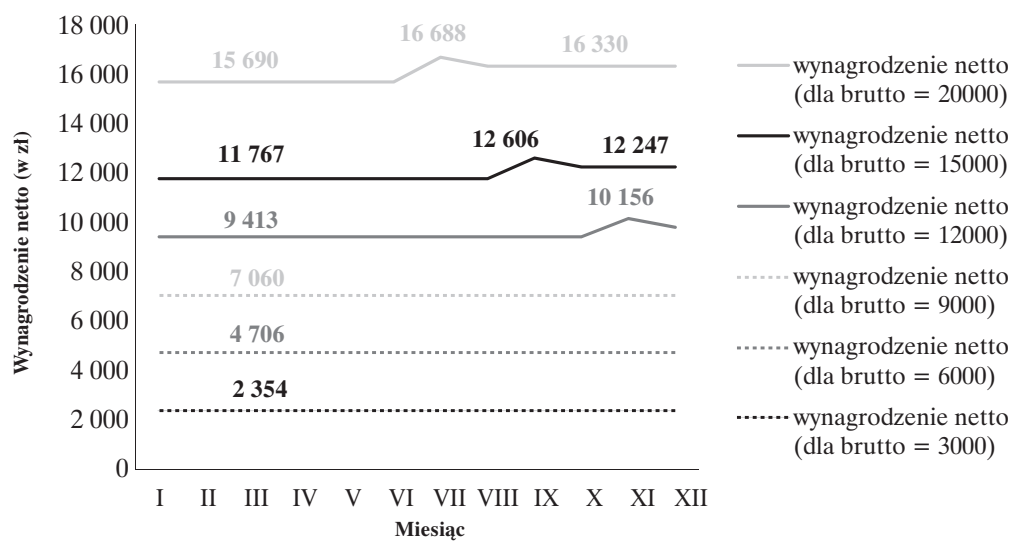

Źródło: opracowanie własne na podstawie: Kalkulator wynagrodzeń. Pozyskano z: http://samozatrudnienie.kalkulator-plac.eu/porownywarka-wysokosci-wynagrodzen (10.10.2016).

najwyższych wartości analizowanych wysokości miesięcznych zarobków, zaliczka na podatek ostatecznie wzrasta ponadczterokrotnie w stosunku do bazowej wartości. Przy wynagrodzeniu brutto na poziomie $12000 \mathrm{zł}$ ma to miejsce dopiero w grudniu, $\mathrm{w}$ przypadku wynagrodzenia $\mathrm{w}$ wysokości 15000 zł brutto zaliczka radykalnie wzrasta w październiku, natomiast najbardziej odczuwalny wzrost podatku ma miejsce w sierpniu przy wynagrodzeniu $20000 \mathrm{z}$ brutto (rysunek 6). Jednocześnie zwiększeniu o prawie $13 \%$ ulega składka zdrowotna. Równolegle redukowane są składki ZUS zarówno po stronie zleceniobiorcy, jak i zleceniodawcy. Transformacje te sprawiają, że po charakterystycznym jednorazowym „skoku” wynagrodzenia netto o ok. 6-7\%, wynagrodzenie miesięczne stabilizuje się na poziomie o ok. $4 \%$ wyższym od wynagrodzenia początkowego. Brak możliwości stosowania zwiększonych kosztów uzyskania przychodów po osiągnięciu przepisowego limitu nie jest wiec wbrew pozorom dotkliwy dla wynagrodzenia netto.

Odwrotna sytuacja ma natomiast miejsce przy tych samych wielkościach wynagrodzenia brutto, które osoba zatrudniona otrzymuje $\mathrm{z}$ tytułu świadczenia pracy w ramach umowy o dzieło. Brak objecia tej umowy składkami ZUS nie pozwala na zmniejszenie podstawy opodatkowania. Jednocześnie ze względu na niemożność stosowania kosztów uzyskania przychodu ani w wysokości $50 \%$, ani też na poziomie standardowym po przekroczeniu ustawowego limitu, zaliczka na podatek rośnie ostatecznie o $65 \%$. W rezultacie, po wyczerpaniu limitu wielkość wynagrodzenia netto jest wyraźnie mniejsza przez kolejne miesiace (rysunek 7).

Przy zarobkach brutto rzędu 20000 zł spadek wynagrodzenia netto do $98 \%$ wynagrodzenia początkowego ma miejsce już w czerwcu, a w kolejnych miesiacach stabilizuje się na poziomie $92 \%$ wynagrodzenia początkowego. W przypadku wynagrodzenia w wysokości 15000 zł i 12000 zł zmniejszenia następują odpowiednio we wrześniu i październiku, wynosząc w efekcie również $92 \%$ wynagrodzenia początkowego. Brak możliwości stosowania autorskich kosztów uzyskania przychodu w umowie o dzieło po przekroczeniu limitu ustawowego można zatem uznać za dotkliwy z punktu widzenia wynagrodzenia netto. Co więcej, im wyższe są zarobki, tym bardziej dotkliwa jest strata wynikajaca ze zwiększonej zaliczki na podatek dochodowy.

Udział wynagrodzenia netto w strukturze całkowitego kosztu po stronie zleceniodawcy albo zamawiającego dzieło jest zatem rosnący dla umowy zlecenia i malejący dla umowy o dzieło (rysunki 8 i 9). Okazuje się, że stosowanie autorskich kosztów uzyskania przychodu w umowie o dzieło jest najbardziej opłacalne przy wynagrodzeniu brutto na poziomie 6000 i 9000 zł miesięcznie. Natomiast przy mie- 
Rysunek 7. Umowa o dzieło z 50\% KUP - miesięczne wynagrodzenie netto w perspektywie rocznej dla sześciu poziomów wynagrodzenia brutto

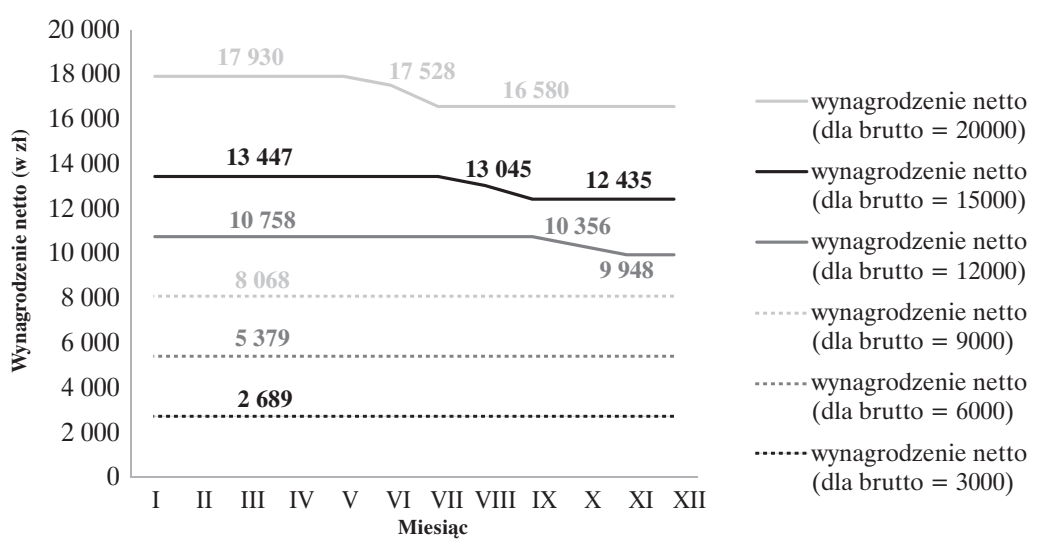

Źródło: opracowanie własne na podstawie: Kalkulator wynagrodzeń. Pozyskano z: http://samozatrudnienie.kalkulator-plac.eu/porownywarka-wysokosci-wynagrodzen (10.10.2016).

Rysunek 8. Struktura całkowitego rocznego kosztu zleceniodawcy z tytułu umowy zlecenia z $50 \%$ KUP

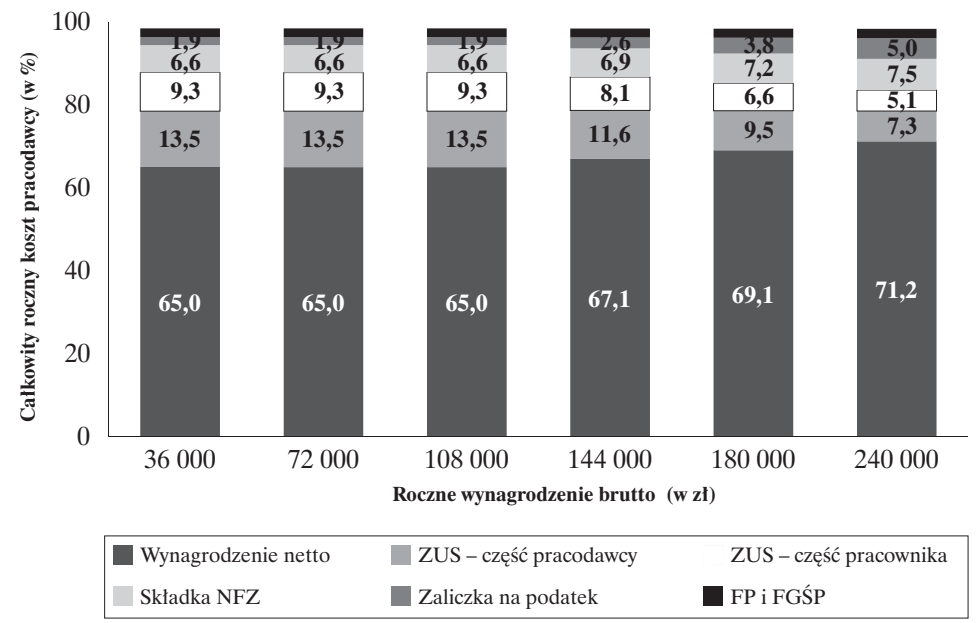

Źródło: opracowanie własne na podstawie: Kalkulator wynagrodzeń. Pozyskano z: http://samozatrudnienie.kalkulator-plac.eu/porownywarka-wysokosci-wynagrodzen (10.10.2016).

sięcznych zarobkach w wysokości 20000 zł brutto wynagrodzenie netto nieznacznie różni się od wynagrodzenia otrzymywanego z tytułu stosowania 20\% KUP. Ogólnie rzecz biorace, można stwierdzić, że wraz ze wzrostem przychodu korzystanie z $50 \%$ KUP czyni wynagrodzenie netto z umowy zlecenia coraz bardziej korzystnym, natomiast $\mathrm{w}$ przypadku umowy o dzieło przyczynia się do zmniejszenia jego wartości.

\section{Wynagrodzenie netto przy umowie o pracę oraz jednoosobowej działalności gospodarczej}

Umowa o prace wiąże się $\mathrm{z}$ reguły ze stałymi kosztami niezależnie od wielkości wynagrodzenia i wymiaru czasu pracy. Koszty te wynoszą 111 zł 25 gr miesięcznie, w przypadku gdy podatnik uzyskuje przychody z tytułu jednego, stosunku pracy albo 
Rysunek 9. Struktura całkowitego rocznego kosztu zamawiającego dzieło z tytułu umowy o dzieło z $50 \%$ KUP

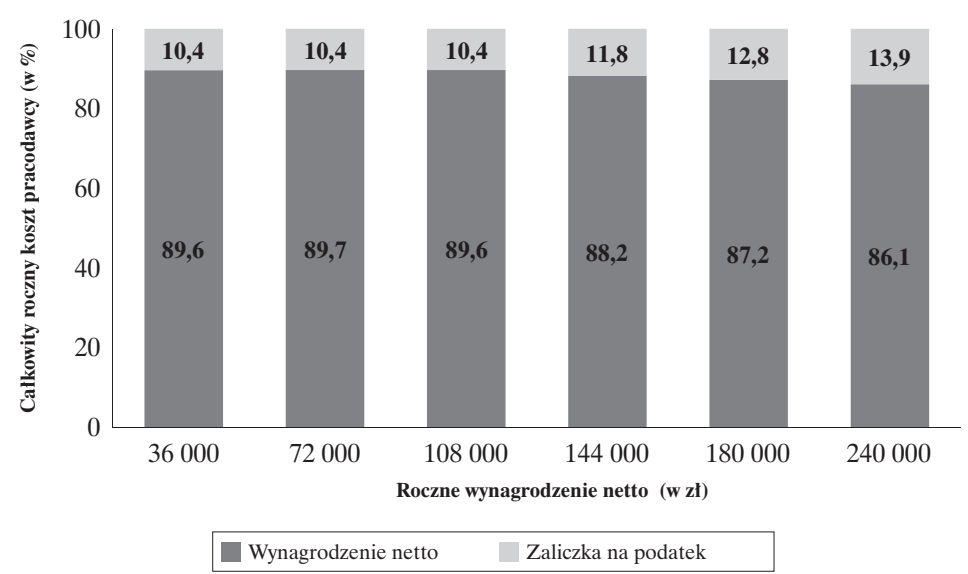

Źródło: opracowanie własne na podstawie: Kalkulator wynagrodzeń. Pozyskano z: http://samozatrudnienie.kalkulator-plac.eu/porownywarka-wysokosci-wynagrodzen (10.10.2016).

139 zł 06 gr miesiecznie, w przypadku, gdy miejsce stałego lub czasowego zamieszkania podatnika jest położone poza miejscowością, w której znajduje się zakład pracy, a podatnik nie uzyskuje dodatku za rozłąkę (art. 22 ust. 2 pkt 1 oraz 3 ustawy o podatku dochodowym od osób fizycznych, 1991). Pracownik nie ma zatem wplywu na koszty uzyskania przychodu. Przedsiębiorca natomiast, $\mathrm{z}$ punktu widzenia optymalizacji podatkowej, dąży do osiągania wysokich kosztów, które po odliczeniu od przychodu pomniejszą podstawę opodatkowania. Co więcej, składki ZUS przedsiębiorcy nie sa uzależnione od wysokości wynagrodzenia brutto tak jak dzieje sie to w przypadku pracownika na etacie. Podczas gdy składki ZUS z tytułu umowy o prace rosna proporcjonalnie do wielkości wynagrodzenia, przedsiębiorca opłaca składki w wysokości stałej bez względu na wysokość przychodu.

W analizowanym przykładzie zakładamy, że wynagrodzenie brutto $\mathrm{z}$ pracy wynosi tyle samo co dochód $\mathrm{z}$ działalności gospodarczej oraz, dla uproszczenia, że podatnik nie ponosi innych kosztów niż składki na ubezpieczenie społeczne i zdrowotne. $\mathrm{Z}$ porównania wynagrodzenia netto $\mathrm{z}$ umowy o prace $\mathrm{i}$ dochodu netto $\mathrm{z}$ działalności gospodarczej wynika, że prowadzenie firmy zaczyna być opłacalne już przy wynagrodzeniu netto ze stosunku pracy na poziomie 1,5 tys. zł. Taka tendencja utrzymuje się przez okres dwóch lat, gdy zastosowanie maja preferencyjne składki ZUS. Gdy przedsiębiorcę zaczynają natomiast obowiązywać składki standardowe, próg opłacalności działalności gospodarczej w odniesieniu do umowy o pracę wynosi $5000 \mathrm{zl}$. Zestawienie prezentowane na rysunku 10 pokazuje, że od momentu „przełamania” tego progu roczny dochód netto z działalności gospodarczej rośnie szybciej niż roczne wynagrodzenie netto z umowy o pracę. „Przejście” na liniową stawkę podatku jest opłacalne w momencie osiągnięcia dochodu z działalności gospodarczej na poziomie 8500 zł brutto przy składkach preferencyjnych oraz 9000 zł brutto przypadku opłacania składek w standardowej wysokości.

Zamieniając ze swoim pracodawcą formę zatrudnienia ze stosunku pracy na działalność gospodarczą, należy mieć na uwadze, że nie będzie możliwości skorzystania z preferencyjnych składek ZUS. Ze składek tych wyłączeni są bowiem przedsiębiorcy, którzy prowadzą bądź w okresie ostatnich 60 miesięcy kalendarzowych przed dniem rozpoczęcia wykonywania działalności gospodarczej prowadzili pozarolniczą działalność oraz podatnicy wykonujący działalność gospodarczą na rzecz byłego pracodawcy, dla którego wykonywali czynności wchodzące w zakres rozpoczętej działalności w bieżącym albo poprzednim roku kalendarzowym (art. 18a Ustawy o systemie ubezpieczeń społecznych, 1998). 
Rysunek 10. Zestawienie rocznego wynagrodzenia netto z umowy o pracę oraz rocznego dochodu netto $z$ działalności gospodarczej na podstawie rocznego przychodu/wynagrodzenia brutto $w$ przedziale $12000 \mathrm{zt}-120000 \mathrm{z \dagger}$

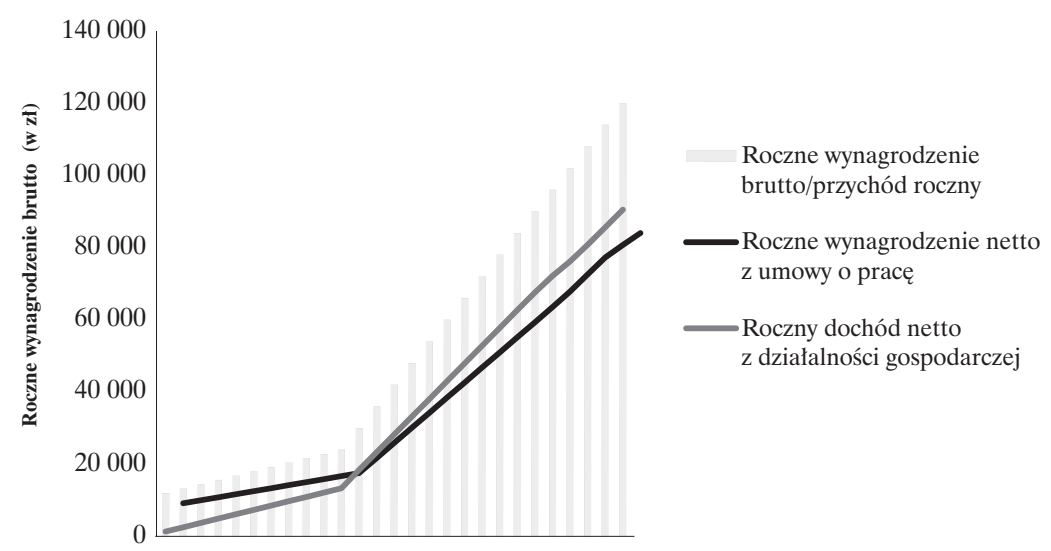

Źródło: opracowanie własne na podstawie: J. Szlęzak-Matuszewicz (2011). Pracując na własną rękę nie masz urlopu, ale więcej zarobisz. Pozyskano z: http://www.wirtualnemedia.pl/artykul/pracujac-nawlasna-reke-nie-masz-urlopu-ale-wiecej-zarobisz (10.10.2016).

\section{Pomniejszone i standardowe składki ZUS w działalności gospodarczej}

Przedsiębiorca prowadzący indywidualną działalność gospodarczą przez pierwsze dwa lata działalności może opłacać składki ZUS w wysokości 30\% minimalnego wynagrodzenia. Po tym czasie musi płacić składki w standardowej wysokości, czyli przynajmniej $60 \%$ prognozowanego przeciętnego wynagrodzenia miesięcznego. Niezależnie od czasu prowadzenia działal- ności, wysokość składek na ubezpieczenie zdrowotne stanowi $75 \%$ wartości przeciętnego miesięcznego wynagrodzenia w sektorze przedsiębiorstw w IV kwartale poprzedniego roku. Przedmiotem analizy struktury przychodu przedsiębiorcy pod kątem składek i zaliczki na podatek są oba wskazane warianty. W analizie składników przychodu założono, że koszty jego uzyskania wynoszą $30 \%$, nie jest opłacana składka chorobowa, a przedsiębiorca stosuje liniową formę opodatkowania. Ponadto, w celu uproszczenia analizy nie uwzględniono podatku VAT.

Tabela 2. Roczny dochód netto z tytułu prowadzenia jednoosobowej działalności gospodarczej z ulgą i bez ulgi w składkach ZUS

\begin{tabular}{|c|c|c|}
\cline { 2 - 3 } \multicolumn{1}{c|}{} & \multicolumn{2}{c|}{ Roczny dochód netto (zl) } \\
\hline Roczny przychód (zI) & $\begin{array}{c}\text { Samozatrudnienie - ulga przy } \\
\text { składkach ZUS }\end{array}$ & $\begin{array}{c}\text { Samozatrudnienie - brak ulgi } \\
\text { przy składkach ZUS }\end{array}$ \\
\hline 36000 & 29152 & 23221 \\
\hline 72000 & 60364 & 54433 \\
\hline 108000 & 91576 & 85645 \\
\hline 144000 & 122788 & 116857 \\
\hline 180000 & 154000 & 148069 \\
\hline 240000 & 206020 & 200089 \\
\hline
\end{tabular}

Źródło: opracowanie własne na podstawie: Kalkulator samozatrudnienia. Pozyskano z: http://kalkulator. racymind.pl/web/samozatrudnienie (10.10.2016). 
Największe różnice $\mathrm{w}$ dochodzie netto widoczne są dla przychodów na poziomie 36000 zł rocznie, gdzie brak ulgi w składkach ZUS powoduje o $26 \%$ niższy dochód netto niż w przypadku posiadania ulgi. Dysproporcje te stają się coraz mniejsze w miarę zwiększania się wartości osiąganego przychodu. Na poziomie $108000 \mathrm{zl}$ i 240000 zł przychodu rocznie różnica wynosi odpowiednio już tylko $7 \%$ i $3 \%$. Zgodnie z przyjętymi założeniami obniżone składki ZUS przez pierwsze dwadzieścia cztery miesiące trwania działalności sprawiają, że udział dochodu netto w przychodzie to ponad $80 \%$ na każdym z analizowanych poziomów wysokości zarobków.

Obniżone składki ZUS wynoszą rocznie 1952,76 zł i jest to wielkość stała niezależnie od wysokości przychodu. Dlatego też udział składek ZUS w strukturze jest malejący w miarę wzrostu zarobków: wynosi $5 \%$ przy najniższych zarobkach, a ostatecznie osiagga poziom $1 \%$. Składka zdrowotna wynosi rocznie 5420,16 zł, a jej udział w strukturze przychodu ma tę sama tendencję co udział składek ZUS. W rezultacie udział dochodu netto rośnie wraz ze wzrostem przychodu.

Podobna tendencja ma miejsce w przypadku opłacania składek na poziomie $60 \%$ prognozowanego przeciętnego wynagrodzenia miesięcznego (rysunek 11). Na pierwszym poziomie wysokości przychodu, tj. $36000 \mathrm{zł}$ brutto rocznie, umowa o prace jest bardziej korzystna forma zarobkowania niż samozatrudnienie ze względu na nieco większy udział dochodu netto w strukturze $(64,7 \%$ w pracy na etacie i $64,5 \%$ w samozatrudnieniu). Na kolejnych poziomach udział wynagrodzenia netto rośnie już zdecydowanie na korzyść działalności gospodarczej. Składki ZUS wynoszą rocznie 12 742,92 zł, natomiast składka zdrowotna, podobnie jak w poprzednim przypadku, wynosi 3 467,40 zł. Przy zarobkach równych 36000 zł rocznie składki ZUS stanowią dosyć znaczące obciążenie dla przedsiębiorcy osiagając $23,8 \%$ w strukturze przychodu. Ponadto, osoba samozatrudniona po dwóch latach prowadzenia działalności zobowiązana jest do opłacania składek na Funduszu Pracy.

$\mathrm{Z}$ punktu widzenia optymalizacji dochodu netto własna działalność gospodarcza nie jest bardziej atrakcyjna forma zarobkowania niż umowa zlecenia zarówno ze standardowymi, jak i autorskimi kosztami uzyskania przychodu, jest to jednak opcja korzystniejsza od umowy o dzieło. W analizowanym przykładzie jedynie przychód w wysokości 20000 zł miesięcznie sprawia, że udział dochodu netto z samozatrudnienia jest delikatnie wyższy niż ten uzyskiwany przy umowie o dzieło z $20 \%$ KUP. W ramach przyjętych założeń, umowa o dzieło z $50 \%$ KUP jest wariantem zde-

Rysunek 11. Struktura przychodu przy samozatrudnieniu bez ulgi przy składkach ZUS

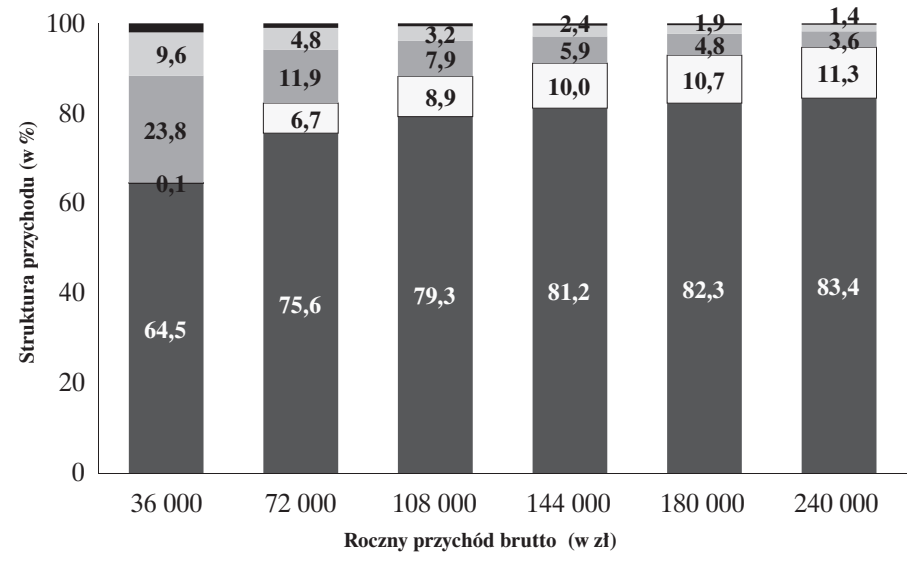

Dochód netto $\square$ Zaliczka na podatek $\square$ Składki ZUS $\quad$ Składka NFZ $\square$ Fundusz Pracy

Źródło: opracowanie własne na podstawie: Kalkulator wynagrodzeń. Pozyskano z: http://samozatrudnienie.kalkulator-plac.eu/porownywarka-wysokosci-wynagrodzen (10.10.2016). 
cydowanie maksymalizującym wysokość wynagrodzenia netto. Biorąc jednak pod uwagę, że koszty uzyskania przychodu w działalności gospodarczej mogą w praktyce kształtować się na poziomie znacznie odbiegającym od przyjętych tutaj $30 \%$, również udział dochodu netto w samozatrudnieniu może się zmieniać.

\section{Podsumowanie}

Rozstrzygnięcie, która z analizowanych $\mathrm{w}$ artykule form zarobkowania jest najatrakcyjniejsza z punktu widzenia maksymalizacji wynagrodzenia zależy od wysokości rocznych przychodów przy każdej z form, które następnie mogą mieć wpływ na wysokość zaliczki na podatek dochodowy, składek na ubezpieczenia społeczne i ubezpieczenie zdrowotne. Przy każdej z form znaczenie ma także, czy możliwe jest skorzystanie z 50\% kosztów uzyskania przychodów, co związane jest z przeniesieniem praw autorskich. Dodatkowo, przy samozatrudnienia istotny może być fakt, czy przedsiębiorca może być zakwalifikowany jako rozpoczynający działalność gospodarczą.

Co istotne, $\mathrm{w}$ artykule przeanalizowano, jak wysokość wynagrodzenia netto przy poszczególnych formach zarobkowania kształtuje się na przestrzeni roku (w kolejnych miesiącach). W przypadku umowy o pracę ze standardowymi i autorskimi kosztami uzyskania przychodu w rocznej perspektywie zaobserwowano, iż miesięczne wynagrodzenia netto maleje. Powodem tej sytuacji jest znaczny wzrost zaliczki na podatek przy stosunkowo niewielkiej redukcji składek ZUS. Miesięczne wynagrodzenie netto rośnie natomiast w trakcie roku przy umowie zlecenia z $20 \%$ i $50 \%$ KUP, czego przyczyną jest nieznaczne zwiększenie zaliczki na podatek przy jednocześnie radykalnej redukcji składek ZUS. Istotnym wnioskiem płynącym z analizy umowy zlecenia jest fakt, że przekroczenie limitu, do którego możliwe jest stosowanie $50 \%$ KUP nie wpływa ujemnie na trend miesięcznego wynagrodzenia netto. Odwrotna sytuacja ma jednak miejsce w przypadku miesięcznych zarobków netto z umowy o dzieło z 50\% KUP, które wykazują tendencje malejąca po przekroczeniu ustawowego limitu. Jedynie w przypadku umowy o dzieło z 20\% KUP miesięczne wynagrodzenie netto wykazuje stabilność przez okres całego roku dla każdego z sześciu poziomów wynagrodzenia brutto.

Warto zwrócić uwagę, że w przypadku umów cywilnoprawnych i samozatrudnienia, im wyższe są poziomy wynagrodzeń brutto, tym mniejsze stają się różnice pomiędzy umowami pod kątem ich zyskowności. Innymi słowy, gdy mamy do czynienia z niższymi poziomami wynagrodzenia, wówczas większe znaczenie należy przypisać wyborze odpowiedniej umowy. Obserwacja ta nie ma zastosowania do umowy o pracę, ponieważ w jej przypadku decyzja o wyborze standardowych bądź autorskich kosztów ma z punktu widzenia maksymalizacji wynagrodzenia netto największe znaczenie przy wysokich zarobkach.

W jednoosobowej działalności gospodarczej stała wartość składek ZUS i składki zdrowotnej sprawia, że ich udział w strukturze przychodu maleje wraz ze wzrostem zarobków na korzyść udziału dochodu netto. Atrakcyjność samozatrudnienia z perspektywy optymalizacji korzyści finansowych nie jest łatwo porównywalna z pozostałymi formami. Podstawowe znaczenie dla tych korzyści mają bowiem koszty uzyskania przychodu i forma opodatkowania, które nie są ściśle ustalone dla przedsiębiorcy.

Powyższe wnioski mają istotne znaczenie praktyczne zarówno dla osób stojących przed wyborem formy zarobkowania, jak i dla odpowiednich organów władzy, w szczególności ministrów właściwych do spraw pracy oraz finansów, planujących wprowadzenie nowych reguł opodatkowania oraz oskładkowania poszczególnych form zarobkowania.

\section{Przypisy}

1 W tym zakresie mogą występować nieliczne wyjątki, np. w przypadku wspólnika spółki z ograniczoną odpowiedzialnością czy akcjonariusza spółki akcyjnej zatrudnionych na postawie umowy o pracę w charakterze członka zarządu.

\section{Bibliografia}

Eurostat (2014). Eurostat Labour Market Database. Pozyskano z: http://ec.europa.eu/eurostat/data/ database (10.10.2016).

Główny Urząd Statystyczny (2015). Rocznik Statystyczny Pracy 2015. Warszawa. Pozyskano z: http:// stat.gov.pl/obszary-tematyczne/roczniki-staty- 
styczne/roczniki-statystyczne/rocznik-statystycznypracy-2015,7,4.html (17.11.2016).

Hatfield, I. (2015). Self employment in Europe. Report. London: Institute for Public Policy Research.

Kalkulator wynagrodzeń. Pozyskano z: http:/ /samozatrudnienie.kalkulator-plac.eu/porownywar ka-wysokosci-wynagrodzen (10.10.2016).

Kalkulator samozatrudnienia. Pozyskano z: http:// kalkulator.racymind.pl/web/samozatrudnienie (10.10.2016).

Kołodziej, A. (2016). Jednolity podatek od 2018 roku. Zniknie Pit, składki na ZUS i NFZ. Мопеy. pl. Pozyskano z: http://www.money.pl/gospodarka/ wiadomosci/artykul/jednolity-podatek-od-2018roku, 135,0,2092935.html

Obwieszczenie Ministra Rodziny, Pracy i Polityki Społecznej z dnia 21 grudnia 2015 r. w sprawie kwoty ograniczenia rocznej podstawy wymiaru składek na ubezpieczenia emerytalne i rentowe w roku 2016 oraz przyjętej do jej ustalenia kwoty prognozowanego przeciętnego wynagrodzenia, M.P. z 28.12.2016r., poz. 1292. Pozyskano z: https://www.mpips.gov.pl/aktualnosci-wszystkie/ art,5539,7574,kwota-ograniczenia-rocznej-podstawywymiaru-skladek-na-ubezpieczenia-emerytalne-irentowe-w-roku-2016.html, (17.11.2016)
Państwowa Inspekcja Pracy (2016). Sprawozdanie Gtównego Inspektora Pracy z dziatalności Państwowej Inspekcji Pracy - 2015. Warszawa. Pozyskano z: https://www.pip.gov.pl/pl/f/v/156451/Sprawozdanie\%202015.pdf (10.10.2016).

Shane, S. i Venkataraman, S. (2000). The Promise of Entrepreneurship as a field of Research. Academy of Management Review, 25(1), 217-226, http:// dx.doi.org/10.5465/AMR.2000.2791611

Szlęzak-Matuszewicz, J., Pracujac na wtasna ręke nie masz urlopu, ale więcej zarobisz. Pozyskano z: http://www.wirtualnemedia.pl/artykul/pracujacna-wlasna-reke-nie-masz-urlopu-ale-wiecej-zaro bisz\# (10.10.2016).

Timmons, J.A. (1999). New Venture Creation: Entrepreneurship for the $21^{s t}$ Century, wyd. V. Boston: Irwin/McGraw-Hill.

Ustawa z dnia 26 lipca 1991 r. o podatku dochodowym od osób fizycznych, Dz.U. $1991 \mathrm{Nr}$ 80, poz. 350 z późn. zm.

Ustawa z dnia 13 października 1998 r. o systemie ubezpieczeń społecznych, Dz.U. 1998 Nr 137, poz. 887.

Wyrok Wojewódzkiego Sądu Administracyjnego w Warszawie z 10 lutego 2010 r., III SA/Wa 1987/07. 